\title{
Temporal and Quantitative Analyses of Stem Lesion Development and Foliar Disease Progression of Peach Rust in California
}

\author{
Alejandra Soto-Estrada and James E. Adaskaveg
}

Department of Plant Pathology, University of California, Riverside 92521.

Accepted for publication 11 July 2003.

\begin{abstract}
Soto-Estrada, A., and Adaskaveg, J. E. 2004. Temporal and quantitative analyses of stem lesion development and foliar disease progression of peach rust in California. Phytopathology 94:52-60.

The development of rust epidemics caused by Tranzschelia discolor on leaves and stems of cling peach was studied in California orchards. Sporulating stems lesions were only detected from late March until July in 1997 and 1998. When rust was present in the fall, the quadratic equation $Y=-82.51+1.97 \mathrm{JD}-0.01 \mathrm{JD}^{2}$ using Julian day (JD) described the incidence of sporulating lesions on stems of cv. Andross $\left(R^{2}=0.73\right.$; $P \leq 0.001)$ in the following spring season. Late-season rust epidemics occurred in 1996 and 1997. Incidence of rust on leaves of cvs. Andross and Ross was $<10 \%$ from April through July and 80 to $100 \%$ by October/November. In 1998, early-season epidemics developed with disease incidence at 28 to $56 \%$ by July/August in two cv. Andross orchards. No disease was observed during the 1999 growing season.
\end{abstract}

ABSTRACT

Rust on peach (Prunus persica) is caused by the biotrophic fungus Tranzschelia discolor (Fuckel) Tranzschel \& Litvinov based on the research of Dunegan (5). The disease also has been reported on almond, apricot, cherry, plum, prune, and nectarine trees. On peach, the disease affects leaves, fruit, and stems (1). Leaf infections develop as angular, chlorotic lesions with rusty orange-brown pustules or uredinia on the lower leaf surface. Fruit infections develop as circular lesions 2 to $3 \mathrm{~mm}$ in diameter that remain green on immature fruit. The expansion of infected tissue during fruit maturation is inhibited. This results in sunken lesions with discolored mesocarp below the lesion on mature fruit. In the center of the lesions, uredinia and urediniospores develop. Urediniospores can also infect current-year peach stems. Stem infections have been found on other Prunus spp., but they are more common on peach (13). During the spring, rusty brown uredinia of the fungus rupture the epidermis of the stems to release urediniospores (8). Later, as the stems grow in circumference, lesions split open lengthwise along the stems $(8,13)$.

Peach rust is an economically important disease. Heavy leaf infection can result in premature defoliation of the tree $(8,13)$; however, in California this rarely occurs on mature peach trees. Defoliation may stimulate flowering during the fall or early winter and may reduce tree vigor or productivity in the subsequent season $(2,9)$. In addition to these indirect losses, fruit infections can result in direct crop loss. Early-season epidemics that occur before fruit expansion during the maturation process result in deformation of fruit and the most severe crop losses. Several major

Corresponding author: J. E. Adaskaveg; E-mail address: jim.adaskaveg@ucr.edu

Publication no. P-2003-1028-01R

(c) 2004 The American Phytopathological Society
Using linear regression analysis, logistic and exponential models best described the development of disease in 1996 and 1997, respectively. In contrast, the monomolecular model best described the disease in 1998. In an analysis of variance comparing disease progress curves on cv. Andross from 1996 to 1998, no significant differences in area under the disease progress curve and $\rho$ were observed, whereas $y_{\max }$ was significantly different $(P<0.001)$. A repeated measures analysis indicated that in a cv. Andross orchard the year of the disease progress curve, time of sampling, and their interaction were highly significant $(P<0.01)$. This indicated a distinct difference between early- and late-season epidemics. Earlyseason development of rust on leaves occurred in years with $\geq 117.3 \mathrm{~mm}$ of total precipitation and maximum temperatures of $\leq 30.2^{\circ} \mathrm{C}$ in April to June.

Additional keywords: disease modeling, inoculum survival, Prunus persica, spore viability. outbreaks have occurred in California since 1925 (13). The last major epidemics in 1995 and 1998 were early-season epidemics with leaf and fruit infections that resulted in considerable economic crop losses to growers in northern California especially on cvs. Andross and Ross. Canneries rejected deformed fruit with more than three lesions and this fruit was diverted to less profitable uses (e.g., juice or animal feed).

Goldsworthy and Smith (8) described the disease cycle of peach rust in California. Stems are infected during outbreaks of the disease on leaves in the fall and the fungus survives as mycelium in symptomless stems during the winter $(8,14)$. In spring, visible stem lesions develop superficially and are not considered damaging to the tree, except for their production of primary inoculum (i.e., urediniospores) that initiates leaf infections during the spring (13). Sporulating stem lesions have been reported on 1- and 2-year-old stems (8). Currently, no information is available as to the specific temporal occurrence of peach stem lesions producing viable urediniospores that function as primary inoculum during the growing season. Depending on spring and summer environments, leaves can be infected throughout the growing season (14). Leaf infections generally occur before fruit infections. Fruit are apparently not susceptible until they are of considerable size (14). Management practices for the disease emphasize multiple applications of fungicides such as wettable sulfur during the spring and early summer to prevent leaf and fruit infections (13). The specific seasonal disease progression on leaves or fruit has not been evaluated previously or modeled on peach or other Prunus spp. Obtaining new information on disease progression could improve disease management programs by optimizing timing of fungicide applications and lead to more efficient use of fungicides to prevent direct crop losses.

Peach rust epidemics occur sporadically in years with excessive wetness during the growing season (13). In most years, rust on

52 PHYTOPATHOLOGY 
leaves can be found in the fall, but in some years, the disease develops to epidemic proportions in the spring and summer seasons. The inconsistent occurrence of epidemics has limited detailed research on the epidemiology of this disease. Because economic losses from peach rust occurred in 1995, we initiated research to monitor and describe the temporal development of sporulating stem lesions of rust. The viability of urediniospores also was evaluated from uredinia collected from leaves and stem lesions of cling peach to validate their significance in the disease cycle. Furthermore, we quantitatively described and comparatively analyzed disease progress curves of rust on leaves for different cultivars and in different growing seasons.

\section{MATERIALS AND METHODS}

Stems infections. Monitoring for stem infections of rust was done in commercial cling peach orchards from 1997 to 1999 that ranged in age from 5 to 7 years at the beginning of the study. The disease was evaluated in one cv. Andross (Andross-1) and one cv. Ross orchard in 1997 in Marysville, CA, where outbreaks of the disease had occurred in 1995. In 1998 and 1999, disease incidence was evaluated in two cv. Andross orchards in Marysville (Andross-1) and Yuba City (Andross-2), CA. These locations are within a main cling peach growing area of the state. Evaluations began in February and continued to November during each year. For this, 40 1-year-old stems from 20 untreated trees (two from each tree) in each orchard were randomly collected and evaluated macro- and microscopically for sporulating stem lesions. Stems with at least one lesion were considered diseased. Incidence was determined for each sampling date and was expressed as a percentage of the number of stems with one or more lesions of the total number of stems sampled. Additionally, in November 1997 and 1998, 100 stem lesions that had been sporulating in the spring were labeled on five untreated trees. These lesions were evaluated weekly for new sporulation from March to June 1998 and 1999. Data based on incidence of sporulating stem lesions on cv. Andross recorded from February to July (Julian days [JD] 55 to 205) 1997 and 1998 were standardized using the mean of the three sampling dates during the 2 years for both orchards. Individual sampling dates did not vary more than 14 days from each other. Arcsine square-root transformation was performed and the data were analyzed using general linear model procedures of the Statistical Analysis System (version 6.12, SAS Institute, Cary, NC).

Viability of urediniospores from stem lesions and leaves. Viability of urediniospores was evaluated at every sampling date when leaves and stems were monitored for rust infections during the 1996 to 1998 growing seasons. Urediniospores were collected with a transfer needle, mixed in a test tube with sterile distilled water containing $0.01 \%$ Tween 20, and agitated. Four evenly spaced $20-\mu 1$ drops of each urediniospore suspension were placed in a $10-\mathrm{cm}$ petri dish containing water agar. Plates were incubated in the dark at $20^{\circ} \mathrm{C}$ for 18 to $24 \mathrm{~h}$ and 100 urediniospores were evaluated for each drop of inoculum. A urediniospore was considered germinated when the germ tube length was at least twice the width of the spore. Standard deviation values were calculated for means obtained for each sample date.

Disease progress. Incidence of leaves with symptoms and signs of rust was evaluated in the same orchards as those used for monitoring stem infections as described previously. In addition, the Andross-1 orchard was evaluated in 1996. Assessments were made in each orchard periodically from late March to November in each year of the study. Sampling intervals ranged from 14 to 24 days in the spring and early summer seasons once disease was detected to 30 to 40 days in late summer and fall. For this, 50 leaves from each of 40 stems (approximately $50 \mathrm{~cm}$ long) collected from five nontreated trees in each of four rows (two stems per tree for a total of 2,000 leaves for the four rows) were evaluated for rust lesions at each sampling date. Leaves with one or more uredinia were considered diseased. Disease incidence was expressed as a percentage of the number of leaves infected of the total number of leaves sampled. Additionally, the incidence of fruit infections at harvest was evaluated based on 200 fruit for each of four single-tree replications in the Andross-1 orchard in 1996, 1997, and 1998.

Analysis of disease progress curves using linear models. To construct disease progress curves, average disease incidence values for each cultivar and location were plotted for each sampling time. Disease incidence data from JD 128 to 279,114 to 315 , and 127 to 218 were used for 1996, 1997, and 1998, respectively. Disease progress curves were fitted to four growth models using linear regression analysis $(3,11,12)$. Equations with linear parameters from each of three models of the Richard's family of growth curves, i.e., monomolecular $(\ln [1 /(1-y)]=$ $\left.\ln \left[1 /\left(1-y_{0}\right)\right]+r_{M} t\right)$, logistic $\left(\ln [y /(1-y)]=\ln \left[y /\left(1-y_{0}\right)\right]+r_{L} t\right)$, and Gompertz $\left(-\ln [-\ln y]=-\ln \left[-\ln \left(y_{0}\right)\right]+r_{G} t\right)$, as well as the exponential model $\left(\ln [y]=\ln \left(y_{0}\right)+r_{E} t\right)$, were used as predicted equations to statistically compare linearly transformed empirical data. Variables of the models are $y=$ disease incidence as a proportion from 0 to 1 at time $t, y_{0}=$ the initial disease level, and $r^{*}=$ rate of disease increase for each model. Coefficients of determination $\left(R^{2}\right)$, mean square error (MSE) values, and plots of standardized residuals versus the predicted values were obtained using regression and analysis of variance (ANOVA) procedures of the SAS program. For comparisons, recalculated $R^{2}$ and MSE values (designated $R^{* 2}$ and MSE*) were used as described by Campbell and Madden (3) and Neher et al. (11). For this, transformed predicted disease values were backtransformed to the original scale and regressed on the observed

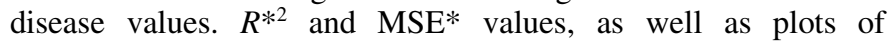
standardized residuals versus the predicted values, were used to select the best model to describe disease progress curves for each orchard site and year.

Statistical comparison of peach rust epidemics between orchard sites and years. For each orchard location and year, linear equations were calculated for each row sampled based on the model that best described the disease progress curve from the Richard's family of equations. To statistically compare epidemics in one orchard over three growing seasons and in two locations in 1 year using the same or different cultivars, area under the disease progress curve (AUDPC), $y_{\max }$, the rate parameter $\left(r^{*}\right)$, and the weighted mean absolute rate of disease $(\rho)$ were estimated for selected Richard's family equations used to describe the rust epidemics in the above section (3). To estimate $\rho$, a shape parameter of $m=0$ or 2 for monomolecular or logistic models, respectively, was used in characterizing $y_{\max }$ (3). The dependent variables AUDPC, $y_{\max }, r^{*}$, and $\rho$ were then compared using ANOVA procedures. Least significant difference (LSD) mean separation procedures were then used for significant variables.

Repeated measures ANOVA was used to test violations in assumptions of independence of samples for data collected on the same experimental unit in a single plot (3) according to SAS Institute protocols. For this, sampling dates between different years were standardized using the median values among the sample dates for each disease progress curve. Disease incidence data from JD 85 to 315 were used. Individual sampling dates did not vary more than 10 days from each other in the growing seasons from 1996 to 1998 .

Environmental conditions. Daily average and maximum and minimum air temperatures, as well as precipitation records from March to October of 1995 to 1999 , were obtained from the California Irrigation Management Information System (CIMIS) network for Marysville and Yuba City, CA. Temperature data were summarized as monthly averages (degrees Celsius), and precipitation data were summarized as monthly totals (millimeters). 


\section{RESULTS}

Stem infections. The incidence of sporulating stem lesions on two cultivars of cling peach during the 1997 and 1998 growing seasons is presented in Figure 1A. In each growing season, sporulating lesions were observed from spring to early summer, but were not detected as the season progressed beyond August. The number of lesions found on each stem mostly ranged from one to three, but occasionally up to nine were found. In 1997, the incidence of lesions was considerably higher on cv. Andross than on cv. Ross. No sporulating lesions were observed on sampled stems in the two orchards evaluated in the 1999 season.

Arcsine square-root-transformed data of the incidence of sporulating stem lesions for cv. Andross were fitted to a quadratic equation. Predicted and observed values were plotted over time expressed in JD (Fig. 1B). Observed values are the average incidence of sporulating lesions in Andross-1 for 1997 and 1998 and Andross-2 for 1998. The equation expressed as $Y=-82.51+$ $1.97 \mathrm{JD}-0.01 \mathrm{JD}^{2}$, where $Y=$ incidence of sporulating stem lesions and JD = Julian days at sampling, described incidence of stems with sporulating lesions during the spring and early summer seasons when rust was detected in the previous fall. The model was highly significant $(P<0.001)$ and the coefficient of determination $\left(R^{2}\right)$ was 0.73 . The equation indicates that the highest incidence of sporulating lesions is expected from middle April to early June (JD 107 to 161). Incidence of sporulating lesions was $0 \%$ on or before JD 55 and also after JD 205. None of the 100

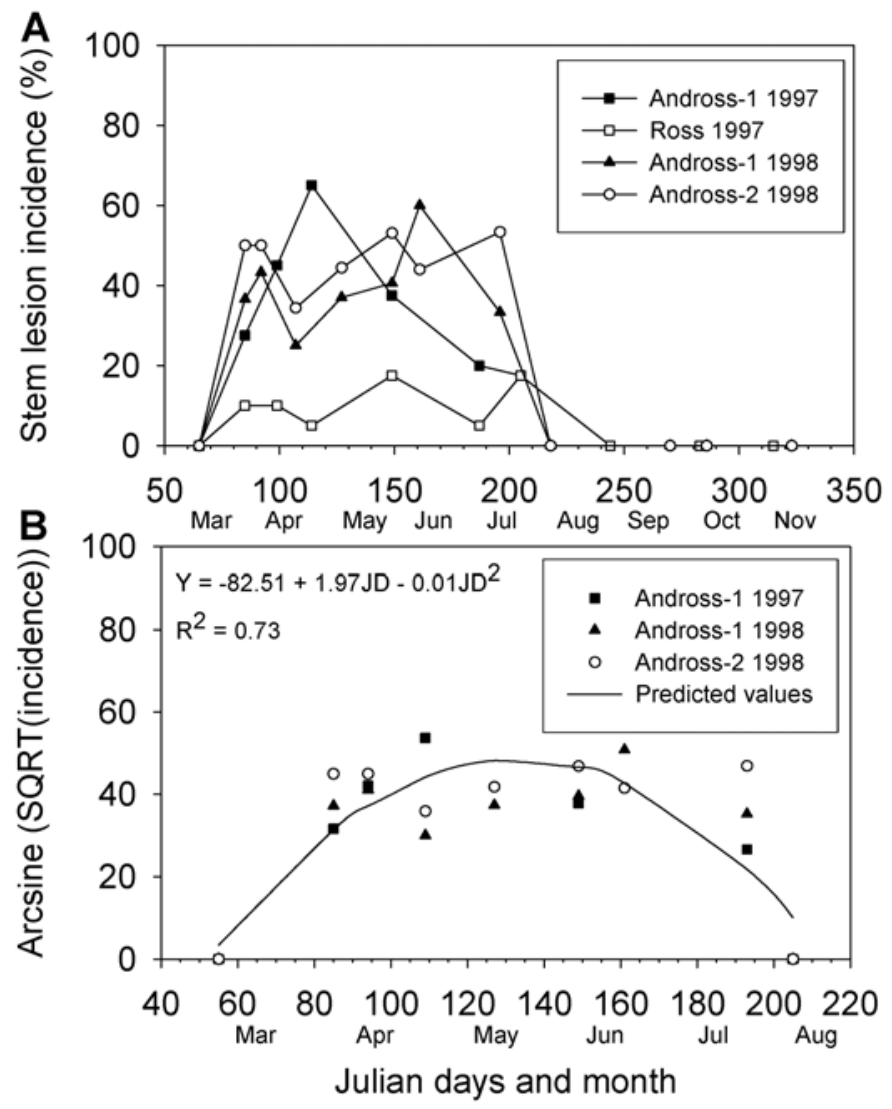

Fig. 1. Occurrence of sporulating stem lesions caused by Tranzschelia discolor in three commercial orchards located in Marysville (Andross-1 and Ross) and Yuba City (Andross-2), CA. A, Incidence of sporulating rust lesions on 1-year-old stems of cling peach cvs. Andross and Ross for the 1997 and 1998 growing seasons. B, Arcsine square-root (SQRT) of the decimal value of disease incidence and of the predicted values (curve) of rust lesions on stems of cling peach cv. Andross. For each sampling date, the mean of 40 1-year-old stems (two stems from each of 20 nontreated trees), each approximately $50 \mathrm{~cm}$ long, is shown. Stems with at least one lesion were considered diseased. stem lesions tagged on five different trees in the fall of 1997 and 1998 sporulated in the spring of 1998 and 1999, respectively. Urediniospores were rarely found in these lesions.

Viability of urediniospores. Viability of urediniospores collected from stem lesions, as measured by germination, is shown in Figure 2. In general, viability was highest in the spring between JD 85 and 127 with 16 to $82.8 \%$ germination. Germination then decreased to 0 to $2 \%$ at JD 205 for both cultivars in 1997 and 1998. Standard deviations of percent germination of urediniospores from stem lesions was generally less than $5 \%$ but ranged from 0 to $10.4 \%$. Viability of urediniospores collected from infected peach leaves in the field is shown for each sampling date in Figure 3. Urediniospore germination varied greatly among years and also among sampling dates for both cvs. Andross and Ross. In general, in each year, urediniospore germination was 50.3 to $86.7 \%$ in the spring when uredinia were first observed on leaves (JD 99 to 150) and germination was 31.0 to $70.5 \%$ in the fall (JD 279 to 323 ). Urediniospore germination was highly variable during the summer months (JD 187 to 265). Within each sampling date, variation in germination was minimal. Standard deviations of percent germination ranged from 0 to $10.6 \%$ but was generally less than $5 \%$ for all sampling dates and years (Fig. 3).

Disease progress curves. Disease progress curves for rust on leaves of two cling peach cultivars for the 1996 and 1997 growing seasons are presented in Figure 4A. In these years, disease increased to high levels $(\geq 80 \%)$ in the fall. In 1996, however, incidence of peach rust on cv. Andross increased to $<10 \%$ in the spring (JD 180), whereas in 1997, no disease was detected at this time. In 1997, disease incidence on cv. Andross increased gradually from $3 \%$ in late July (JD 205) to $15 \%$ in September (JD 244 ) and to $100 \%$ in November (JD 315). On cv. Ross, disease
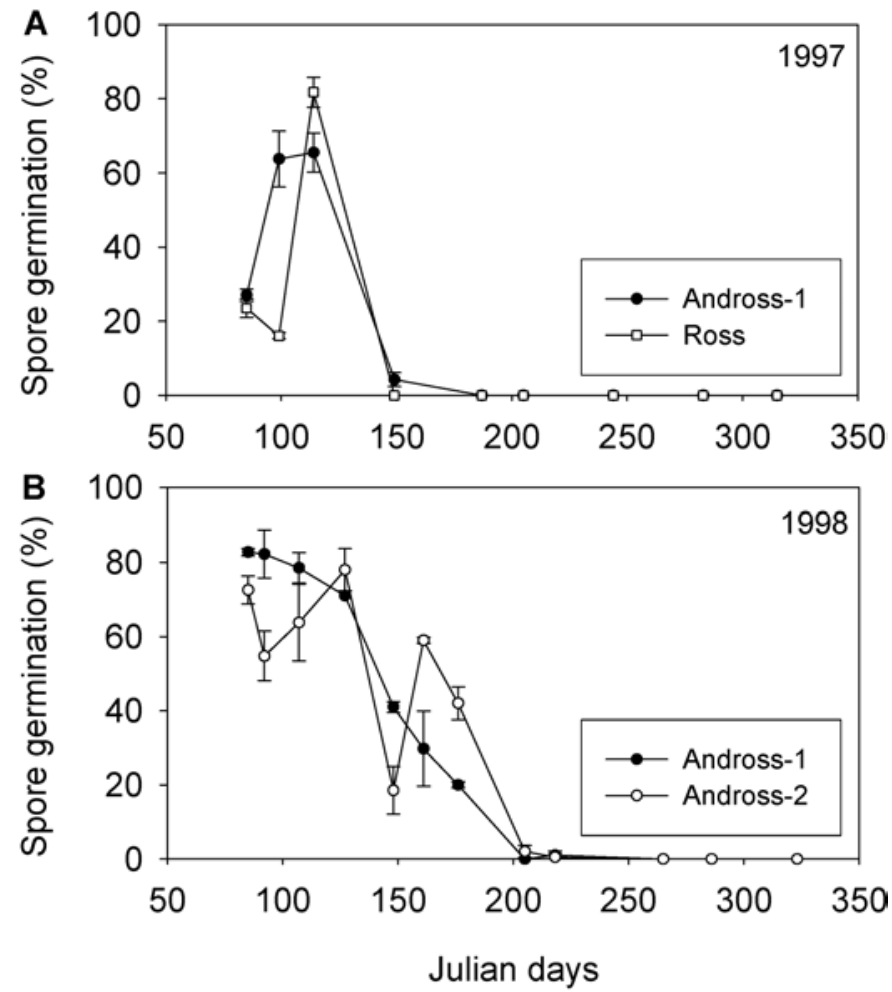

Fig. 2. Mean germination of urediniospores of Tranzschelia discolor collected from uredinia on stem lesions of cling peach cvs. Andross and Ross for the A, 1997 and B, 1998 growing seasons. In 1997, germination was evaluated from samples collected in Marysville (Andross-1), whereas in 1998, samples were collected in Marysville and Yuba City (Andross-2). Each data point represents the mean percent germination based on 100 urediniospores for each of four replications for each sampling date after 18 to $24 \mathrm{~h}$ of incubation on water agar. Bars represent the standard deviation of each mean. 
incidence was less than 3\% between April (JD 114) and September (JD 244) but increased to $20 \%$ in October (JD 283) and $99 \%$ in November (JD 315).

Incidence of peach rust progressed differently in 1998 (Fig. 4B). In this year, disease increased to high levels early in the growing season before JD 220 and did not increase further in the late growing season. In the Andross-1 orchard in Marysville, the highest disease incidence was 56\% in August (JD 218), whereas in the Andross-2 orchard in Yuba City, the highest incidence was $28 \%$ in July (JD 205). By November (JD 323), these values decreased to 37 and $22 \%$, respectively. Although rust was monitored during the 1999 growing season, no disease was observed on leaves. In each year of the study, defoliation did not occur in any of the orchards until late October. Average fruit infections at harvest (late July/early August) in the Andross-1 orchard were $2.1 \%$ in $1996,0 \%$ in $1997,9.1 \%$ in 1998 , and $0 \%$ in 1999.
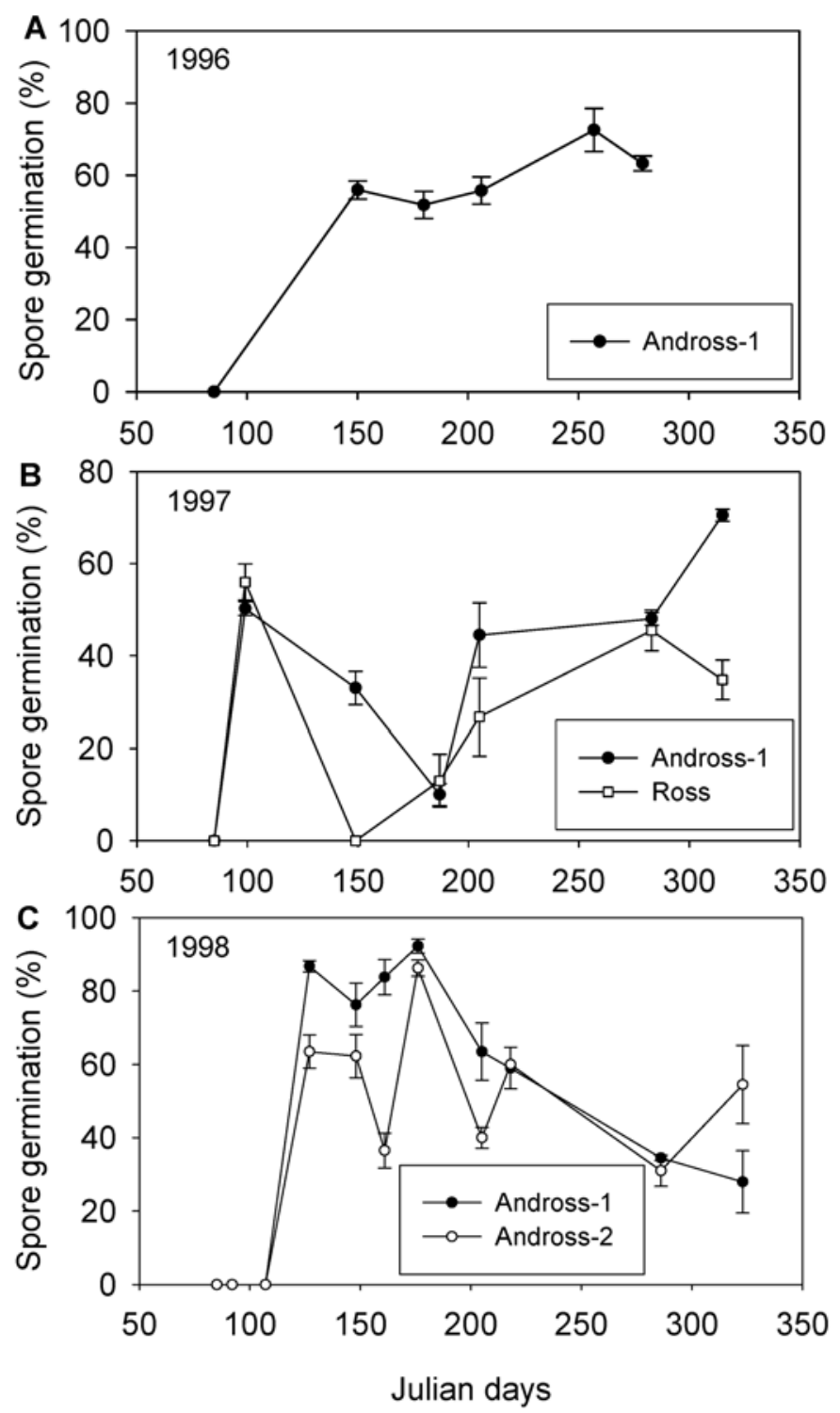

Fig. 3. Mean germination of urediniospores of Tranzschelia discolor collected from uredinia on leaves of cling peach cvs. Andross and Ross for the A, 1996, B, 1997, and C, 1998 growing seasons. In 1996 and 1997, germination was evaluated from samples collected in Marysville (Andross-1), whereas in 1998, samples were collected in Marysville and Yuba City (Andross-2). Each data point represents the mean percent germination based on 100 urediniospores for each of four replications for each sampling date after 18 to $24 \mathrm{~h}$ of incubation on water agar. Bars represent the standard deviation of each mean.
Analysis of disease progress curves using linear models. Results of linear regression analyses in the evaluation of four growth curve models for describing disease progress of cling peach rust on cvs. Andross and Ross during 1996 to 1998 are shown in Table 1. The exponential and logistic models best described disease progress on both cultivars from April to November in the 1996 and 1997 growing seasons. In 1998, the monomolecular and Gompertz models best described disease progress for Andross- 1 in Marysville, whereas the monomolecular model best described disease progress for Andross-2 in Yuba City. Graphs of residuals versus predicted values were randomly distributed (described as OK in Table 1) for the models described previously for each orchard site and year.

Statistical comparison of peach rust epidemics between orchard sites and years. For each orchard location and year, linear equations were calculated for each row sampled from equations described in the proceeding section (Table 2). Thus, the logistic model was selected for Andross-1 in 1996/1997 and Ross in 1997, whereas the monomolecular model was selected for Andross-1 and Andross-2 in 1998. For each equation, $\rho$ is shown based on the assumption that $y_{\max }$ equals 1 .

The dependent variables AUDPC, $y_{\max }, \rho$, and $r^{*}$ that were calculated for each row (e.g., replication) using the model (logistic or monomolecular) that best described the disease progress curve were statistically compared for Andross-1 from 1996 to 1998 ("all years"), for Andross-1 and Ross in 1997, and for Andross-1 and Andross-2 in 1998 (Table 3). In comparing these parameters for Andross-1 for "all years," only the $F$ test for differences in $y_{\max }$ among disease progress curves was significant $(P<0.001)$. Values for AUDPC $(P>0.3439), \rho(P>0.6031)$, and $r^{*}(P>0.1050)$

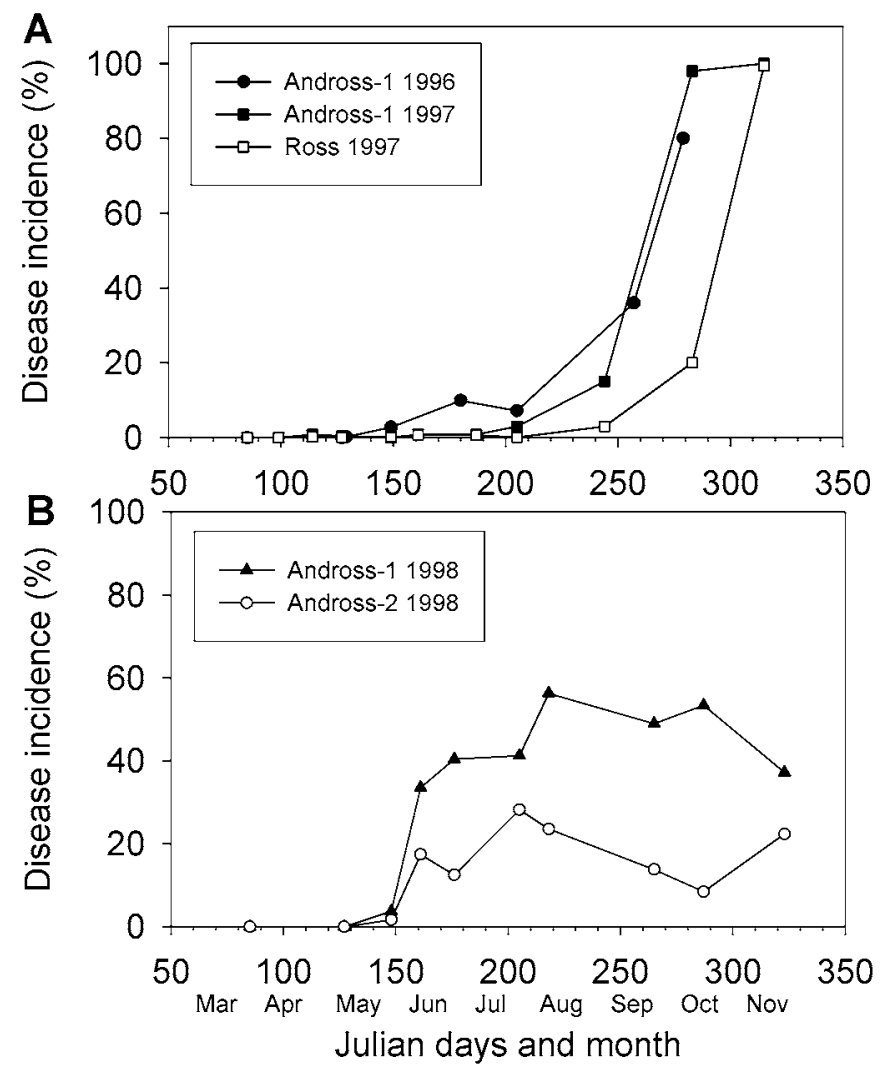

Fig. 4. Disease progress curves of rust caused by Tranzschelia discolor on leaves of cling peach cvs. Andross (orchards 1 and 2) and Ross. A, Growing seasons of 1996 and 1997. B, Growing season of 1998. Evaluations were made in three commercial orchards located in Marysville (Andross-1 and Ross) and Yuba City (Andross-2), CA. Disease incidence for each cultivar was based on 2,000 leaves from 40 stems (50 leaves per stem) collected from nontreated trees at each evaluation date. Leaves with at least one lesion were considered diseased. 
were not significantly different. Mean separation of $y_{\max }$ values for disease progress curves for Andross- 1 for each year are shown in Table 4. The $y_{\max }$ value for the disease progress curve for 1998 was significantly different from those of 1996 and 1997. In 1997, none of the parameters was significant (Table 3). In 1998, AUDPC $(P<0.003)$ and $y_{\max }(P<0.007)$ were significantly different for the two Andross orchard sites (Table 3). In Andross-1 and Andross-2, AUDPC values were 1,390.0 and 2,594.3 (LSD = 646.4), whereas $y_{\max }$ values were 30.9 and $56.3(\mathrm{LSD}=15.6)$, respectively.

Results of the repeated measures analysis of disease progress among curves obtained for rust epidemics in orchard Andross-1 from 1996 to 1998 are shown in Table 5. The $F$ test indicated that there was a significant overall difference among the disease progress curves $(P<0.004)$, but not among the rows $(P>0.6343)$. There was a significant difference of time $(P<0.0007)$ on disease incidence, indicating a significant increase in disease over time. A significant effect $(P<0.0011)$ of the interaction of time and disease progress curves indicated that the increase in disease over time varied significantly among the years of the study. No significant effect $(P>0.9165)$ of the interaction of time and row was observed (Table 5).

Environmental data. In 1998, as well as 1996, when disease increased early in the season (before JD 180), total precipitation ranged from 163.4 to $184.5 \mathrm{~mm}$ for April, May, and June. In 1997 when late-season epidemics occurred or in 1999 when no epidemics were observed, total precipitation ranged from 36.6 to 43.1 $\mathrm{mm}$ in Marysville (Fig. 5) and 43.9 to $88.3 \mathrm{~mm}$ in Yuba City (Fig. 6) for the same time period. In Yuba City, average/maximum temperatures were $20.4 / 28.0^{\circ} \mathrm{C}$ in June of 1998 when disease incidence was high in the early part of the growing season. These temperatures were higher in June of 1996, 1997, and $1999\left(24.3 / 33.0^{\circ} \mathrm{C}, 22.7 / 30.8^{\circ} \mathrm{C}\right.$, and $21.3 / 30.7^{\circ} \mathrm{C}$, respectively) when disease incidence was low in the early part of the season (Fig. 6). Similarly, in Marysville, average/maximum temperatures of $22.3 / 30.2^{\circ} \mathrm{C}$ were observed in June of 1998 and $25.0 / 34.1^{\circ} \mathrm{C}$, $24.7 / 33.0^{\circ} \mathrm{C}$, and $22.6 / 31.7^{\circ} \mathrm{C}$ in 1996,1997 , and 1999 , respectively (Fig. 5).

TABLE 1. Summary of linear regression statistics for evaluation of four growth curve models to describe disease progress of rust caused by Tranzschelia discolor on leaves of cling peach cvs. Andross and Ross in Marysville and Yuba City ${ }^{\mathrm{a}}$

\begin{tabular}{|c|c|c|c|c|c|c|}
\hline Year & Location & Orchard $^{b}$ & Model & $R^{* 2}(\%)$ & MSE* & Residuals \\
\hline \multirow[t]{3}{*}{1996} & Marysville & Andross-1 & Exponential & 78.1 & 0.011 & $\mathrm{OK}$ \\
\hline & & & Monomolecular & 39.9 & 0.144 & Not OK \\
\hline & & & Logistic & 72.4 & 0.024 & OK \\
\hline \multirow[t]{6}{*}{1997} & Marysville & Andross-1 & Exponential & 74.3 & 0.00001 & OK \\
\hline & & & Monomolecular & 14.7 & 0.979 & Not OK \\
\hline & & & Logistic & 75.8 & 0.013 & OK \\
\hline & & & Gompertz & 48.7 & 0.075 & OK? \\
\hline & & & Logistic & 77.9 & 0.014 & OK \\
\hline & & & Gompertz & 40.9 & 0.089 & Not OK \\
\hline \multirow[t]{5}{*}{1998} & Marysville & Andross-1 & Exponential & 62.3 & 0.04 & Not OK \\
\hline & & & Monomolecular & 79.6 & 0.01 & OK \\
\hline & & & Logistic & 68.3 & 0.02 & Not OK \\
\hline & & & Gompertz & 75.4 & 0.011 & $\mathrm{OK}$ \\
\hline & Yuba City & Andross-2 & Exponential & 38.5 & 0.031 & Not OK \\
\hline
\end{tabular}

a Abbreviations: $R^{* 2}=$ recalculated coefficient of determination, and MSE* = recalculated mean square error. Recalculated parameters were done for agreement between observed and predicted transformed $y$ values (i.e., $\left.y^{*}\right)$. Note that only $y$ values greater than 0 and less than $1(100 \%)$ were used for the logistic and Gompertz models. For the monomolecular model, only values less than 1 were used.

${ }^{\mathrm{b}}$ Orchards for cv. Andross were designated Andross-1 and Andross-2 for locations in Marysville and Yuba City, respectively.

TABLE 2. Linear equations describing disease progress of rust and $P$ values for each row of peach cultivars evaluated from 1996 to 1998

\begin{tabular}{|c|c|c|c|c|c|}
\hline Year & Orchard $^{\mathrm{a}}$ & Model & Row & Linear equation & $P=r / 2 m+2$ \\
\hline \multirow[t]{4}{*}{1996} & Andross-1 & Logistic & 1 & $\ln [y /(1-y)]=-3.47+0.011 t$ & 0.0018 \\
\hline & & & 2 & $\ln [y /(1-y)]=-7.51+0.053 t$ & 0.0088 \\
\hline & & & 3 & $\ln [y /(1-y)]=-10.90+0.074 t$ & 0.0123 \\
\hline & & & 4 & $\ln [y /(1-y)]=-5.91+0.032 t$ & 0.0053 \\
\hline \multirow[t]{4}{*}{1997} & Andross-1 & Logistic & 1 & $\ln [y /(y-1)]=-8.88+0.060 t$ & 0.0100 \\
\hline & & & 2 & $\ln [y /(1-y)]=-7.22+0.022 t$ & 0.0037 \\
\hline & & & 3 & $\ln [y /(1-y)]=-9.03+0.037 t$ & 0.0062 \\
\hline & & & 4 & $\ln [y /(1-y)]=-10.77+0.045 t$ & 0.0075 \\
\hline \multirow[t]{4}{*}{1997} & Ross & Logistic & 1 & $\ln [y /(1-y)]=-7.68+0.045 t$ & 0.0075 \\
\hline & & & 2 & $\ln [y /(1-y)]=-9.93+0.044 t$ & 0.0073 \\
\hline & & & 3 & $\ln [y /(1-y)]=-9.87+0.044 t$ & 0.0073 \\
\hline & & & 4 & $\ln [y /(1-y)]=-10.78+0.045 t$ & 0.0075 \\
\hline \multirow[t]{4}{*}{1998} & Andross-1 & Monomolecular & 1 & $\ln [1 /(1-y)]=-0.117+0.036 t$ & 0.0360 \\
\hline & & & 2 & $\ln [1 /(1-y)]=-0.055+0.0025 t$ & 0.0063 \\
\hline & & & 3 & $\ln [1 /(1-y)]=-0.134+0.0035 t$ & 0.0088 \\
\hline & & & 4 & $\ln [1 /(1-y)]=-0.184+0.004 t$ & 0.0010 \\
\hline \multirow[t]{4}{*}{1998} & Andross-2 & Monomolecular & 1 & $\ln [1 /(1-y)]=-0.381+0.009 t$ & 0.0360 \\
\hline & & & 2 & $\ln [1 /(1-y)]=-0.714+0.014 t$ & 0.0070 \\
\hline & & & 3 & $\ln [1 /(1-y)]=-0.209+0.0066 t$ & 0.0017 \\
\hline & & & 4 & $\ln [1 /(1-y)]=-0.264+0.0061 t$ & 0.0015 \\
\hline
\end{tabular}

a Orchards for cv. Andross were designated Andross-1 and Andross-2 for locations in Marysville and Yuba City, respectively. 


\section{DISCUSSION}

In this study, we provide the first temporal model for predicting sporulating rust lesions on 1-year-old peach stems of cv. Andross. New sporulating lesions were first observed in late March after flowering and leaf emergence. Goldsworthy and Smith (8) and Roth (16), however, found stem lesions before leaves unfolded at about the time when the buds were swelling. In our study, the highest incidence of sporulating lesions (up to over 60\%) was observed between JD 107 and 200 in each year and in three different orchards. Thus, different temperatures and precipitation amounts in the 2 years studied (1997 and 1998) did not affect the temporal occurrence of stem lesions. This indicates that the development of stem lesions in the spring is probably more dependent on host physiology. Ogawa and English (13) stated that even in years with severe leaf infection, only about 1 or $2 \%$ of peach stems showed symptoms. This difference in stem lesion incidence could be associated with the peach cultivars studied. Our results suggest that cv. Ross was less susceptible to stem infections than cv. Andross (Fig. 1). Because even in the presence of inoculum no new sporulating lesions were found after JD 205 in our study, stem infections probably do not occur during the spring and summer. These observations are similar to those by Goldsworthy and Smith (8) and Roth (16) who stated that stems are probably infected in the fall when inoculum is present and environmental conditions are favorable. Still, the exact time of stem infection is not known. The implications of these findings directly affect management strategies for the disease. Fungicide programs could be optimized based on the occurrence of the initial inoculum (i.e., stem lesions) and environmental forecasts (19).

In our studies, viable urediniospores were generally found on leaves throughout the growing season in all years. A consistent source of viable leaf inoculum allows for secondary leaf infections and for infection of current-year stems. Variation in germination of urediniospores collected from leaves was probably due to variability in age of the urediniospores, as well as fluctuating and high temperatures during the growing season. Viability of the spores from stem lesions (Fig. 2) followed a similar temporal trend as the incidence of sporulating lesions (Fig. 1) during the spring season. Although urediniospores were present on old lesions of stems collected during the fall, they were no longer viable. This could be due to two reasons. In our histological studies (18), we demonstrated that the expansion of stem infections is inhibited by the development of a wound periderm that prevents

TABLE 4. Comparison of $y_{\max }$ of disease progress curves for peach rust epidemics in one orchard (Andross-1) in Marysville from 1996 to 1998

\begin{tabular}{lcc}
\hline Year & $y_{\max }{ }^{\mathrm{a}}$ & LSD $^{\mathrm{b}}$ \\
\hline 1996 & 78.70 & $\mathrm{a}$ \\
1997 & 98.68 & $\mathrm{a}$ \\
1998 & 30.89 & $\mathrm{~b}$ \\
\hline
\end{tabular}

${ }^{a}$ The variable $y_{\max }$ was compared using an analysis of variance. Values followed by the same letter are not significantly different according to least significant difference (LSD) mean separation procedures.

${ }^{\mathrm{b}} \mathrm{LSD}=23.68$

TABLE 3. Summary of analysis of variance (ANOVA) comparing area under disease progress curve (AUDPC), $y_{\max }, \rho$, and $r^{*}$ of five disease progress curves for peach rust from 1996 to 1998

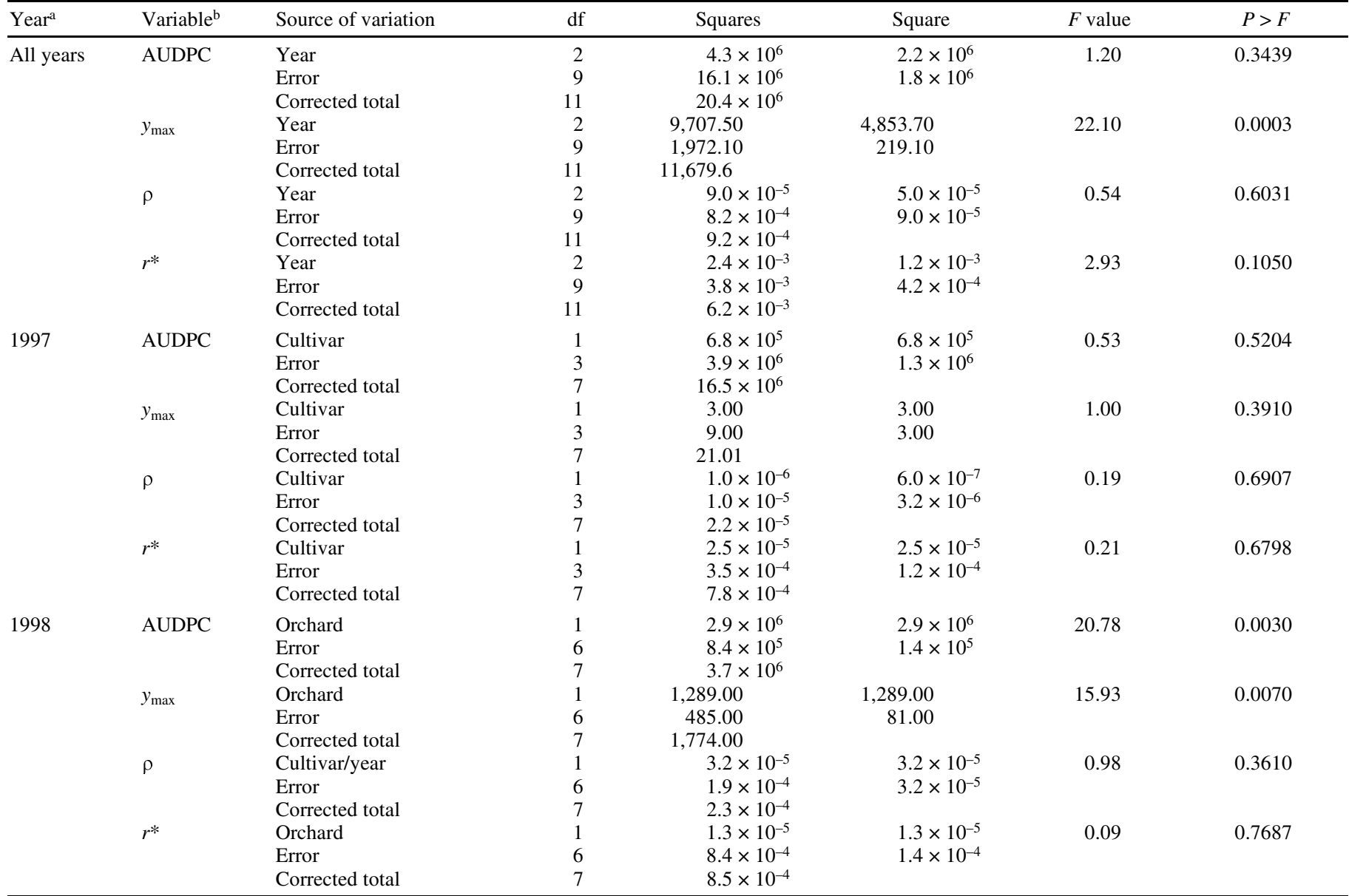

\footnotetext{
a For "all years" (1996 to 1998), the ANOVA was based on cv. Andross (orchard Andross-1); in 1997, it was based on a comparison of cvs. Ross and Andross (orchard Andross-1); whereas in 1998, it was based on a comparison of two orchards of cv. Andross (orchards Andross-1 and Andross-2).

${ }^{\mathrm{b}}$ Dependent variables were AUDPC, $y_{\max }, \rho$ (rho), and rate parameter $\left(r^{*}\right)$.
} 
the fungus from parasitizing living cells. Consequently, no new spores are produced. Secondly, adverse conditions such as high temperatures during the summer may affect the viability of urediniospores produced in these lesions. Urediniospore germination of $T$. discolor is greatly reduced above $30^{\circ} \mathrm{C}$ and spores do not germinate at temperatures above $32^{\circ} \mathrm{C}(4,6,8)$. High temperatures like this were recorded in the field during the summer seasons in the years of our study (Figs. 5 and 6). Furthermore, none of the labeled stem lesions sporulated in the following season. These results indicate that second-year lesions on cv. Andross are not responsible for leaf infections in spring. Contrary to our findings, Goldsworthy and Smith (8) indicated that lesions on second-year stems were able to produce urediniospores. Perhaps differences in wound responses among peach cultivars may explain the difference between the studies. On French prune, a low percentage of urediniospores was found to survive until April on 2 -year-old stems (20). Furthermore, urediniospores that survive on infected prune leaves on trees (7) and on infected fallen leaves (20) were also considered sources of primary inoculum in prune orchards. Germination studies with urediniospores collected from symptomless peach stems and buds during the dormant season

TABLE 5. Summary of the repeated measures analysis of disease progress curves for peach rust in in one orchard (Andross-1) in Marysville from 1996 to $1998^{\mathrm{a}}$

\begin{tabular}{lcccccc}
\hline Source & df & $\begin{array}{c}\text { Sum of } \\
\text { squares }\end{array}$ & $\begin{array}{c}\text { Mean } \\
\text { square }\end{array}$ & $F$ value & $P>F$ & $\begin{array}{c}\text { Wilk's } \\
\text { lambda }\end{array}$ \\
\hline Year & 3 & $9,570.5$ & $3,190.6$ & 9.30 & 0.0040 & $\ldots$ \\
Row & 3 & 611.7 & 203.9 & 0.59 & 0.6343 & $\ldots$ \\
Error & 9 & 3087.5 & 343.1 & $\ldots$ & $\ldots$ & $\ldots$ \\
Time & $\ldots$ & $\ldots$ & $\ldots$ & $\ldots$ & 0.0007 & 0.0284 \\
Time $\times$ year & $\ldots$ & $\ldots$ & $\ldots$ & $\ldots$ & 0.0011 & 0.0047 \\
Time $\times$ row & $\ldots$ & $\ldots$ & $\ldots$ & $\ldots$ & 0.9165 & 0.3239 \\
\hline
\end{tabular}

${ }^{a}$ Repeated measures analysis was performed on median sample dates between each of the disease progress curves evaluated. For each year, samples were collected within 10 days of the median value.
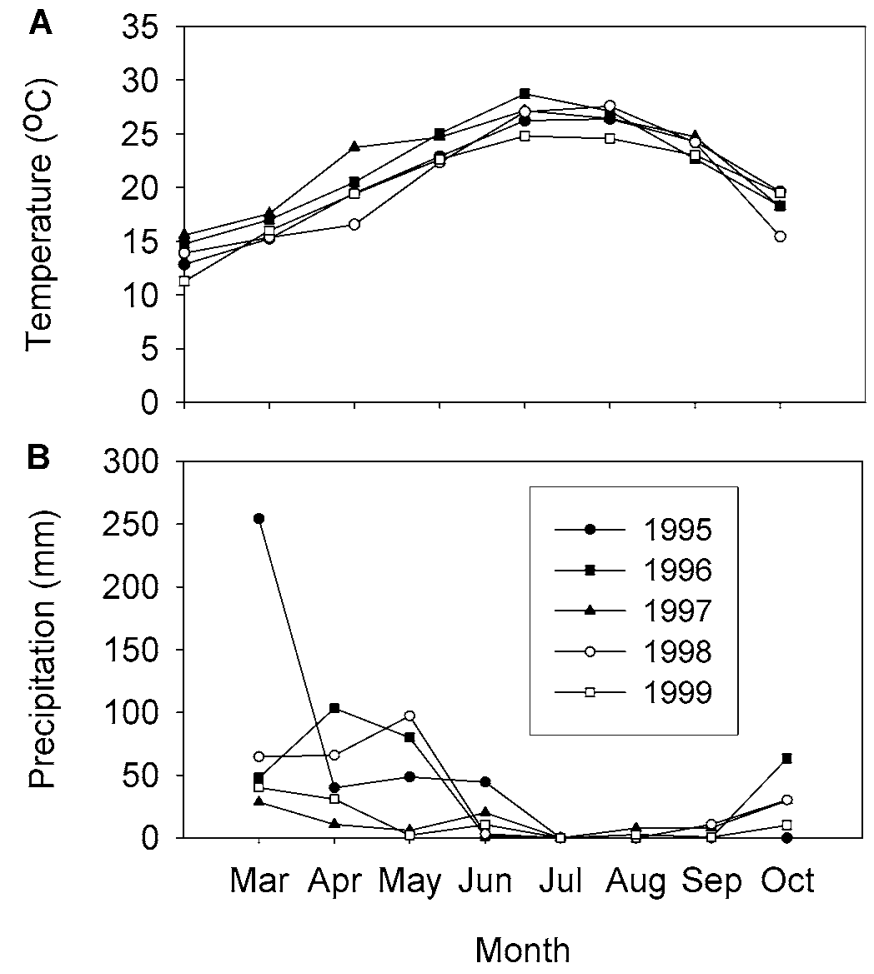

Fig. 5. A, Monthly average temperature and $\mathbf{B}$, precipitation data for the 1995 to 1999 growing seasons in Marysville, CA. Data were obtained from the California Irrigation Management System network. (e.g., February), however, indicated that urediniospores from these tissues were not viable (B. Manji, personal communication). Thus, urediniospores contaminating plant tissues are unlikely to initiate leaf infections of peach in the spring in California.

Rust epidemics caused by $T$. discolor were modeled for the first time on leaves of a Prunus spp. for the 1996 to 1998 growing seasons in California. Late-season rust epidemics occurred in 1996 and 1997. Incidence of rust on leaves of nontreated trees in commercial orchards of cling peach cvs. Andross and Ross increased from $<10 \%$ in July to 80 to $100 \%$ in October/November. In 1998, early-season epidemics developed with disease incidence of 28 and $56 \%$ by July/August in two cv. Andross orchards, with no further increase in disease incidence later in the growing season. The disease progress curve in 1996, however, also had some characteristics of an early-season epidemic. In addition to the high level of disease late in the season, there was an earlyseason increase in disease (9.9\% by JD 180) that was absent in the 1997 curves. The importance of describing early- and late-season epidemics was reflected in the incidence of fruit infections. In 1998, when early-season epidemics occurred, $9.1 \%$ of the fruit evaluated was diseased. In 1997, when late-season epidemics occurred, however, no fruit were diseased at harvest. In 1996, a year with some early-season infections and a high incidence of late-season infections of leaves, $2.1 \%$ of the fruit was infected at harvest. Thus, using four population growth curve models, different models were selected to describe the epidemics in the different years reflecting these seasonal differences in the occurrence of rust epidemics. The logistic and exponential models best described the epidemics in 1996 and 1997 (17), whereas the monomolecular model best described the epidemics in two orchards in 1998. Direct comparisons of the 1996, 1997, and 1998 disease progress curves using AUDPC, $y_{\max }, r^{*}$, and $\rho$, as described by Reynolds and Neher (15), showed that the $y_{\max }$ values for the 1996 and 1997 models were significantly different from the 1998 model (Table 4) based on the ANOVA for all years (Table 3). These data also showed that late-season epidemics had high $y_{\max }$ values late in the season in different years and on different cultivars (e.g., cvs.
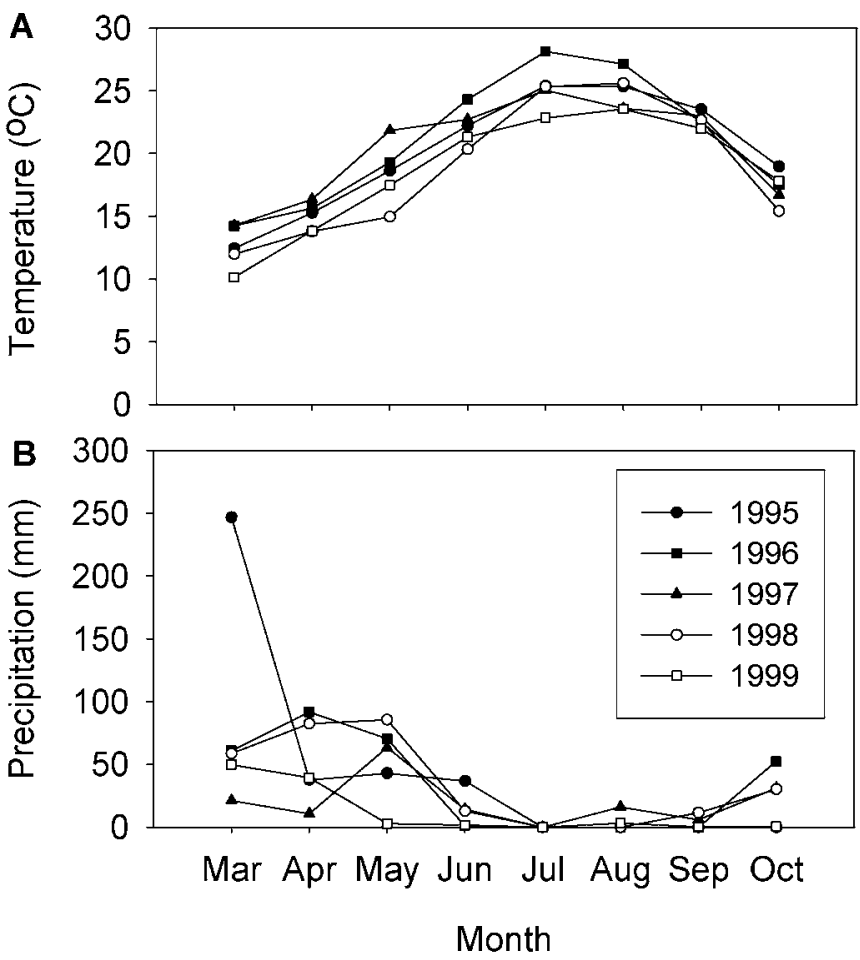

Fig. 6. A, Monthly average temperature and B, precipitation data for the 1995 to 1999 growing seasons in Yuba City, CA. Data were obtained from the California Irrigation Management System network. 
Andross and Ross). Differences among the disease progress curves were also shown in the repeated measures analysis $(3,10)$ with significance in the time parameter and interaction between disease progress curve and time. This indicated that there was a significant increase in disease over time for each of the disease progress curves and that this increase varied significantly among the years of the study. Furthermore, as described by Thal and Campbell (21), the repeated measures analysis allowed a statistical analysis of all disease progress curves for the Andross-1 orchard over the entire season including the curve for 1998 which had an unusual shape, with disease decreasing as the season progressed after reaching a maximum earlier in the year. Thus, data from these studies demonstrate that two distinct types of rust epidemics may occur on peach, the early- and late-season epidemics. The data also show that both types of epidemics can be mathematically defined.

In 1996 and 1997, the exponential model explained the disease progress curves adequately. In the exponential model, as described by Vanderplank (22), the absolute rate of change $(d y / d t)$ increases throughout the epidemic without limitations from factors such as amount of host tissue. Apparently, this model described the epidemic well because the deciduous peach trees began to lose leaves only at the end of the late-season epidemic (last sampling date of each year). Thus, leaf loss on trees did not need to be accounted for in the modeling. In 1996 on cv. Andross and in 1997 on cv. Ross, the logistic model also had a high $R^{* 2}$ and low MSE* similar to the exponential model (Table 1) and it was the best model on cv. Andross in 1997 based on these parameters. The logistic model was preferred over the exponential model in describing these epidemics because a biological interpretation would suggest a limitation in the number of leaves available for infection on a given tree sampled. Thus, the logistic model was selected as the most appropriate model to describe the late-season epidemics and to further analyze and compare the epidemics of different years based on a model in the Richard's family of population growth curves (3). Because rust can progress from low levels at the beginning of the season to high levels at the end of the season (e.g., 1996 and 1997), the disease does not only initiate from primary inoculum (i.e., stem cankers) but also from the development of secondary inoculum and successive infection periods during the growing season.

The monomolecular model best described the peach rust epidemics in 1998 for both orchards. This model assumes that the absolute rate of change $(d y / d t)$ in disease is greatest at the beginning of the epidemic and slows in proportion to the decrease in the amount of disease-free plant tissue (12) or lack of a favorable environment as the season progresses. Because there was no defoliation in the spring and summer, these results suggest that disease levels in an early-season epidemic resulted mainly from primary inoculum and that secondary inoculum probably did not contribute much to the development of the epidemic during the 1998 season. Thus, the establishment of rust on peach leaves in the spring in California most likely depends on the availability of primary inoculum from stem infections and climatic conditions present during the early growing season. This was evident in 1999 when no disease was observed on leaves. There had been no epidemic in the fall of 1998; thus, stem infections apparently did not occur or occurred at low levels. Consequently, we did not find rust stem lesions in the spring of 1999.

The early-season epidemics that developed in 1998 and 1995 (data not shown), as well as the small increase in disease that occurred early in 1996, were related to precipitation and temperature events during the spring (Figs. 5 and 6). In 1998, total precipitation for April, May, and June was $166.2 \mathrm{~mm}$ for Marysville and $180.9 \mathrm{~mm}$ for Yuba City, whereas in 1997, it was $36.6 \mathrm{~mm}$ for Marysville and $88.3 \mathrm{~mm}$ for Yuba City. In 1996, early-season precipitation (163.4 $\mathrm{mm}$ in Marysville and $184.5 \mathrm{~mm}$ in Yuba City from April to June) was also higher than in 1997. Disease inci- dence increased early in the 1996 season; however, no economic epidemic occurred. This difference could be related to the frequency of rainfall or temperature. Roth (16) indicated that a short but heavy rain is not sufficient to cause a rust outbreak, but a light and continuous rain over several days with high relative humidity and favorable temperatures may promote an epidemic. In addition, maximum temperatures in June were 34.1 and $33.0^{\circ} \mathrm{C}$ in Marysville and 33.0 and $30.8^{\circ} \mathrm{C}$ in Yuba City in 1996 and 1997, respectively. In 1995 and 1998, however, maximum temperatures were $\leq 30.2^{\circ} \mathrm{C}$ in both locations. As stated previously, urediniospores of T. discolor do not germinate at temperatures above $32^{\circ} \mathrm{C}$ and germination is greatly reduced above $30^{\circ} \mathrm{C}$. In 1999 , cool temperatures occurred similar to 1998 , but with little precipitation $(<12 \mathrm{~mm}$ in May and June) no disease developed. Thus, the presence of sporulating stem lesions in the spring and frequent precipitation with cool temperatures were probably the optimal conditions for disease development in the spring seasons of 1995 and 1998. Additional studies are needed to model the specific effects of wetness duration and temperature on disease development.

\section{ACKNOWLEDGMENTS}

We thank the California Cling Peach Board for financially supporting this research, D. Thompson and B. Manji for assistance during field experiments, and H. Förster for reviewing the manuscript.

\section{LITERATURE CITED}

1. Adaskaveg, J. E., Soto-Estrada, A., Förster, H., Thompson, D., Hasey, J., Manji, B. T., and Teviotdale, B. 2000. Peach rust caused by Tranzschelia discolor in California. Univ. Calif. Div. Agric. Nat. Res. Publ. No. 8011.

2. Bertrand, P. F. 1995. Rust. Pages 23-24 in: Compendium of Stone Fruit Diseases. J. M. Ogawa, E. I. Zehr, G. W. Bird, D. F. Ritchie, K. Uriu, and J. K. Uyemoto, eds. The American Phytopathological Society, St. Paul, MN.

3. Campbell, C. L., and Madden, L. V. 1990. Introduction to Plant Disease Epidemiology. John Wiley \& Sons, New York.

4. Duan, C. H., Tu, C. C., and Tsai, W. H. 1992. Survival of peach rust fungus in Taiwan. Plant Pathol. Bull. 1:111-114.

5. Dunegan, J. C. 1938. The rusts of stone fruits. Phytopathology 28:411427.

6. Ellison, P. J., Cullis, B. R., Bambach, R. W., and Kable, P. F. 1990. The effect of temperature on in vitro germination and germ tube growth of urediniospores of Tranzschelia discolor. Aust. J. Agric. Res. 41:479-488.

7. Ellison, P. J., McFadyen, L., and Kable, P. F. 1987. Overwintering of Tranzschelia discolor in prune orchards in New South Wales. Aust. J. Agric. Res. 38:895-905.

8. Goldsworthy, M. C., and Smith, R. E. 1931. Studies on rust of cling peaches in California. Phytopathology 21:133-168.

9. Jafar, H. 1958. Studies on the biology of peach rust (Tranzschelia prunispinosae Pers.) in New Zealand. N. Z. J. Agric. Res. 1:642-651.

10. Madden, L. V. 1986. Statistical analysis and comparison of disease progress curves. Pages 55-84 in: Plant Disease Epidemiology, vol. 1. Population Dynamics and Management. K. J. Leonard and W. E. Fry, eds. Macmillan Publishing Co., New York.

11. Neher, D. A., Reynolds, K. L., and Campbell, C. L. 1997. Analysis of disease progress curves using linear models. Pages 29-33 in: Exercises in Plant Disease Epidemiology. L. J. Francl and D. A. Neher, eds. The American Phytopathological Society, St. Paul, MN.

12. Nutter, F. W., Jr., and Parker, S. K. 1997. Fitting disease progress curves using Epimodel. Pages 24-28 in: Exercises in Plant Disease Epidemiology. L. J. Francl and D. A. Neher, eds. The American Phytopathological Society, St. Paul, MN.

13. Ogawa, J. M., and English, H. 1991. Diseases of temperate zone tree fruit and nut crops. Univ. Calif. Div. Agric. Nat. Res. Publ. No. 3345.

14. Pierce, N. B. 1894. Prune rust. J. Mycol. 7:354-363.

15. Reynolds, K. L., and Neher, D. A. 1997. Statistical comparison of epidemics. Pages 34-37 in: Exercises in Plant Disease Epidemiology. L. J. Francl and D. A. Neher, eds. The American Phytopathological Society, St. Paul, MN.

16. Roth, G. 1966. Tranzschelia discolor (Fuck.) Tranz. et Litv. on peaches in Transvaal Lowveld, South Africa. Phytopathol. Z. 56:141-150.

17. Soto-Estrada, A., Adaskaveg, J. E., Manji, B. T., and Hasey, J. 1998. Early and late season rust epidemics on cling peach and their effect on crop production in California. (Abstr.) Phytopathology 88(suppl.):S84. 
18. Soto-Estrada, A., Eddleman, C. D., and Adaskaveg, J. E. 2000. Development and symptom expression of rust caused by Tranzschelia discolor in shoots and leaves of cling peach. (Abstr.) Phytopathology 90(suppl.): S121.

19. Soto-Estrada, A., Förster, H., Hasey, J., and Adaskaveg, J. E. 2003. New fungicides and application strategies based on inoculum and precipitation for managing stone fruit rust on peach in California. Plant Dis. 87:1094-1101.
20. Teviotdale, B. L., Harper, D. M., Michailides, T. J., and Sibbett, G. S. 1994. Lack of effect of stone fruit rust on yield of French prune tress and survival of urediniospores of the pathogen on leaves, shoots, and buds. Plant Dis. 78:141-145.

21. Thal, W. M., and Campbell, C. L. 1988. Analysis of progress of alfalfa leaf spot epidemics. Phytopathology 78:389-395.

22. Vanderplank, J. E. 1963. Plant Diseases: Epidemics and Control. Academic Press, New York. 